\title{
\#CritEdPol: Journal of Critical Education Policy Studies at Swarthmore College
}

Volume 3

Issue 1 Beautiful Experiments

Article 5

January 2021

\section{Teaching in the Service of Fugitive Learning}

Karen Zaino

CUNY Graduate Center, kzaino@gmail.com

Follow this and additional works at: https://works.swarthmore.edu/critedpol

Part of the Education Commons

\section{Recommended Citation}

Zaino, Karen (2021) "Teaching in the Service of Fugitive Learning," \#CritEdPol: Journal of Critical Education Policy Studies at Swarthmore College: Vol. 3 : Iss. 1 , Article 5: 64-80.

DOI: $10.24968 / 2473-912 X .3 .1 .5$

Available at: https://works.swarthmore.edu/critedpol/vol3/iss1/5

This Article is brought to you for free and open access by Works. It has been accepted for inclusion in \#CritEdPol: Journal of Critical Education Policy Studies at Swarthmore College by an authorized administrator of Works. For more information, please contact emayorg1@swarthmore.edu.

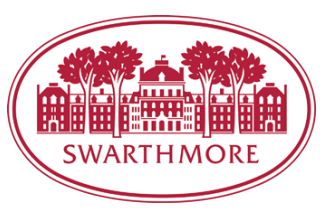




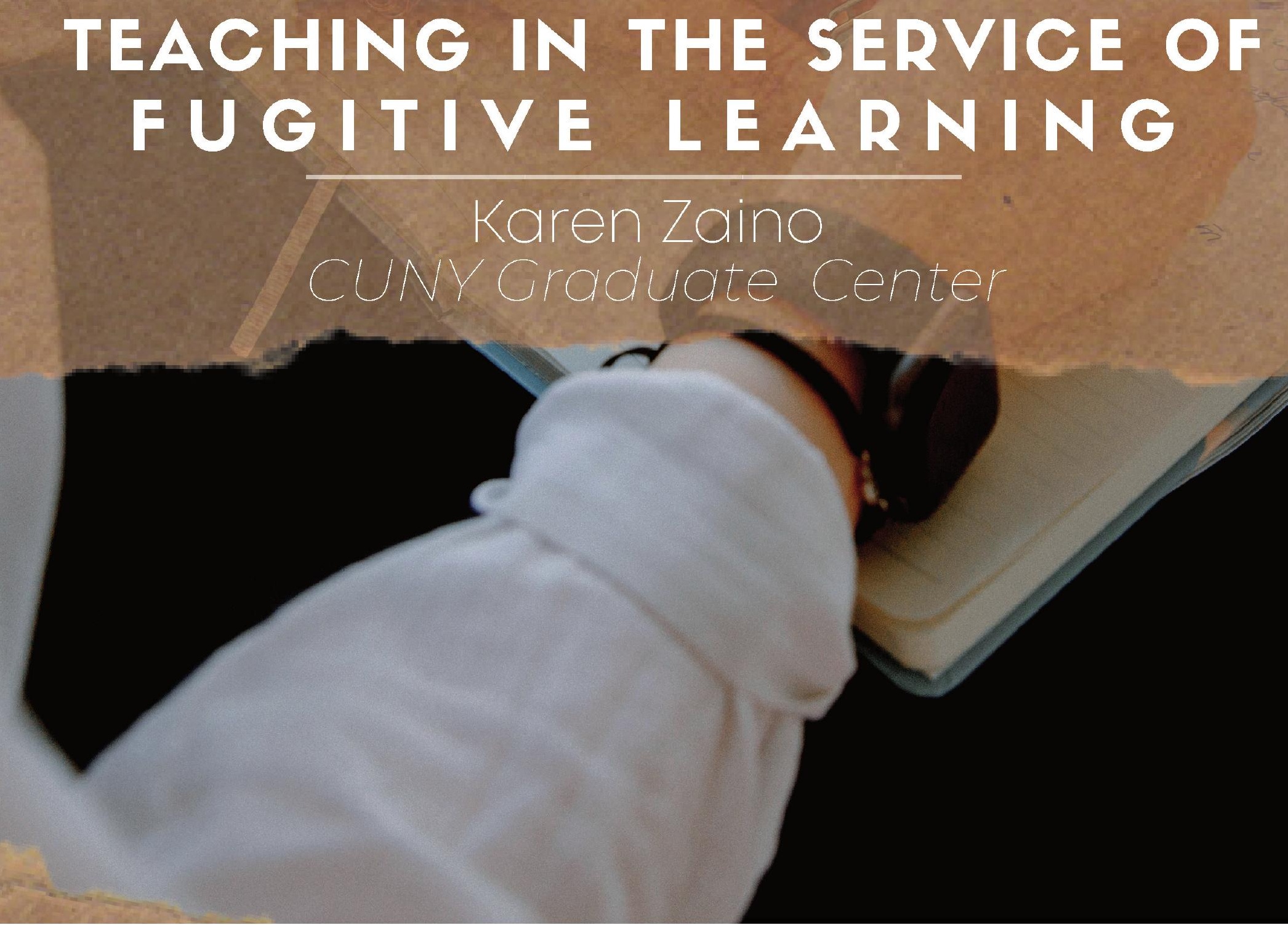




\begin{abstract}
In educational scholarship, abolition and fugitivity have been used to theorize youth literacy practices (The Fugitive Literacies Collective, 2020), teaching in solidarity with Black and brown communities (Love, 2019), and learning as an act of rebellion within the oppressive structures of schooling (Patel, 2016; 2019). Additionally, recent works in sociology (Shedd, 2015) and anthropology (Shange, 2020; Sojoyners, 2016) have thoughtfully and comprehensively documented the ways in which the disciplinary mechanisms of schools serve to contain, surveil, and expunge Black students. This paper draws on these recent scholarly interventions as a lens through which educators might engage with the students who and schools in which they teach. Patel (2016) suggests that authentic learning in schools structured by racial capitalism is a "fugitive act" elusive, subaltern, and, as a result, under-theorized" (Patel, 2016, p. 397). What "fugitive acts of learning" take place in our schools? What relationship to these practices can teachers adopt so that we might "serve and shield" these spaces of "unruly learning" (Patel, 2016, p. 400)?
\end{abstract}

Keyords: fugitivity, abolition, literacy, autoethnography, racial capitalism 


\section{Introduction}

Education scholars such as Leigh Patel (2016, 2019), Bettina Love (2019), and the members of the Fugitive Literacies Collective (2020) have increasingly drawn on the legacy of the Black Radical Tradition (Kelley, 2002; Robinson, 2005) in their work, along with its attendant theories of abolition (Davis, 2005; DuBois, 1935; Gilmore, 2017) and fugitivity (Hartman, 2019; Moten, 2003; Sharpe, 2014). Robinson (2005) coined the term Black Radical Tradition to encompass "the ideological, philosophical, and epistemological natures of the Black movement" that arose in the wake of the global expansion of capitalism, which he argues was racialized from its inception (p. 167). Robinson's excavation of the twin histories of racial capitalism and the Black Radical Tradition has contributed to contemporary interest in abolition and fugitivity among scholars and activists. Abolition has come to mean the dismantling of racial capitalism and its byzantine systems of containment, especially the prison-industrial complex (Davis, 2005). Fugitivity, meanwhile, is "a powerful way to imagine black life that persists in and in spite of" white supremacy (Sharpe, 2014).

In educational scholarship, abolition and fugitivity have been used to theorize youth literacy practices (The Fugitive Literacies Collective, 2020), teaching in solidarity with Black and brown communities (Love, 2019), and learning as an act of rebellion within the oppressive structures of schooling (Patel, 2016; 2019). Additionally, recent works in sociology (Shedd, 2015) and anthropology (Shange, 2020; Sojoyners, 2016) have thoughtfully and comprehensively documented the ways in which the disciplinary mechanisms of schools serve to contain, surveil, and expunge Black students.
This paper draws on these recent scholarly interventions as a lens through which educators might engage with the students who and schools in which they teach. Patel (2016) suggests that authentic learning in schools structured by racial capitalism is a "fugitive act"-elusive, subaltern, and, as a result, under-theorized" (Patel, 2016, p. 397). What "fugitive acts of learning" take place in our schools? What relationship to these practices can teachers adopt so that we might "serve and shield" these spaces of "unruly learning" (Patel, 2016, p. 400)?

This paper documents my attempts to "[see] more clearly the fugitive acts of learning as they occur within oppressive structures" in schools (p. 400). After positioning myself as a white former high school teacher who recently transitioned to doctoral study, I explore the Black Radical Tradition, abolition, and fugitivity-including the oppressive structures in which this tradition foments - in more detail, followed by a review of the educational literature that has taken up these concepts. Then, following Ruth Wilson Gilmore's (2017) idea that "abolitionist critique concerns itself with the greatest and least detail of the arrangements of people and land and resources over time" (p. 227, emphasis in original), I explore the very small world that I inhabited for seven years, an urban high school in the Midwest. I use an autoethnographic case study (Ellis et. al., 2010; Eisenhardt \& Graebner, 2007) to name the concrete ways in which oppressive structures shape this school and identify the fugitive learning that occurs within, around, and in spite of these structures. By proposing these initial sites of fugitive learning in one school, I hope to inspire further conversation and questions about the ways in which educational practitioners might more consistently engage in 
abolitionist practices.

\section{Background}

For the last 12 years, I have worked as an English teacher in public high schools. I generally relied on sociocultural theories to frame my thinking about learning (Nasir et. al., 2006; Vossoughi \& Gutierrez, 2016) and tried to make space in my classroom for students' diverse literacy practices (Morrell, 2008; Paris \& Alim, 2017). But my efforts were sporadic rather than sustained, especially once I moved from a predominantly white community outside Philadelphia to a racially diverse working-class school in a small Northern Kentucky city. In this second context, my classroom practice was shaped by the school-wide contours of rigid curricular mandates, frequent high-stakes testing, and zerotolerance disciplinary policies. These constraining factors are not unusual in urban schools, especially those that serve working-class, racially minoritized students, and I appreciated research that clearly documented these problems ( $\mathrm{Au}, 2016$; Christle et. al., 2005; Kavanaugh \& Fisher-Ari, 2018; Meiners, 2007). At the same time, I was frustrated by scholarly literature that either delineated the perils of restrictive contexts or explored the meaningful learning happening in less restrictive contexts. It was difficult to find research that attempted to theorize meaningful learning that might happen even within the constraints of under-resourced, over-regulated schools.

My introduction into the Black Radical Tradition, fugitivity, and abolition was a short article by Leigh Patel (2016). By characterizing learning "as dialectic to the stratifying cultures of formal education" (p. 397), Patel evokes both the oppressive conditions of schools and the meaningful learning that might take place within them. This article spoke to a desire I didn't know I had until I read about it: I wanted to better understand what happened in my school in a way that neither romanticized my students' learning possibilities nor diminished the subversive acts of learning in which they participated.

As I transitioned from teaching to doctoral education, I wanted to take advantage of the possibilities of this liminal position (Turner, 1967; Cook-Sather, 2011) to consider my observations from my years in school in light of my deeper immersion in theoretical literature. Over the course of this project, I have become increasingly identified with the academy in which I now situate myself, losing some of the intimacy of immediate experience in my school but also gaining important insights into what it means to research and theorize about schools. For instance, as a white researcher, I experience increasing ambivalence about taking up the idea of abolition and fugitivity, practices inseparable from the Black Radical Tradition (Kelley, 2002; Robinson, 2005). What are the limits to my capacity to understand fugitivity and limits to the general applicability of a theory that arose in the very specific context of chattel slavery? What are the dangers of the white appropriation of such theorizing?

However, rather than evade the messiness of exploring these limits, I want to grapple with them directly. I want to acknowledge this tension and consider the extent to which this theory of fugitive learning speaks to something important that is happening in urban schools. In particular, I think it is essential for educational researchers and practitioners to consider the roles we can play in serving and shielding spaces of unruly learning (Patel, 2016, p. 400). Before we can adequately serve and shield such learning, however, we must 
understand what fugitive learning in schools might look like. In the next section, I explore the Black Radical Tradition, fugitivity, and abolition in some detail, first as they have been theorized across a range of scholarship and then how these concepts have recently been applied to educational research.

\section{Conceptual Framework}

The Black Radical Tradition

In his book Black Marxism: The Making of the Black Radical Tradition, Cedric Robinson (2005) begins his theory of the Black Radical Tradition with a critique of Karl Marx's theory of capitalist development. Marx failed to recognize "one of [Europe's] most profound terms of order": racialization (p. 66). Robinson suggests that "racialism and its permutations" have existed in European culture throughout history (p. 27-28). Therefore, as capitalism arose in Europe, it did so in the context of a social order that was always already racialized. As Ruth Wilson Gilmore (2017) succinctly argues, capitalism requires inequality, and racism - which she defines as "the state-sanctioned and/or extralegal production and exploitation of group-differentiated vulnerability to premature death" (2007, p. 247) —enshrines it. Racism provides the organizing logic for capitalist "accumulation by dispossession" (Harvey, 2004), the system through which disinvestment of some becomes a site of wealth accumulation for others.

The Black Radical Tradition arose as racial capitalism became global and gave birth to the transAtlantic slave trade. Kidnapped from their homes by Europeans, enslaved Africans retained their "ontological and cosmological systems" (Robinson, 2005, p. 122). These cultural legacies contributed to the development of a unique resistance movement among members of the Black diaspora. The "collective resistance by Blacks to slavery and colonial imperialism" (p. 169) was undergirded by a "shared sense of obligation to preserve the collective being" (p. 171). These "freedom dreams" (Kelley, 2002) have persisted alongside and serve as a constant foil to racial capitalism, and have manifested in two particular forms of resistance: fugitivity and abolition.

Robinson points out the earliest forms of rebellion against enslavement "took the form of flight" (p. 130). African fugitives were less interested in dismantling plantations than they were in recreating their own communities outside the boundaries of European domination (Robinson, 2005). While escape attempts may have appeared individualistic and spontaneous, Robinson argues that they were part of a collective consciousness that resulted, at times, in maroon societies and, in the case of Haiti, a nation. Fugitivity is an essential unruliness (Hartman, 2019; Moten, 2003; Sharpe, 2014;), the act of "seeing around corners, stockpiling in crevices, knowing the un-rules, being unruly, because the rules are never enough, and not even close" (Macharia, 2013). Fugitive planning has a long history in Black critical thought (Moten and Harney, 2013; Sharpe, 2014; Kelley, 2016). Kelley (2016) suggests that fugitive planning invokes "a memory of freedom, dreams of seizing it, and conspiracies to enact it." In the 21 st century, fugitivity "takes myriad forms, including school truancy, gender nonconformity, border crossing, bench-warrant avoidance, and prison abolition" (Quan, 2017, p. 185). These fugitive activities can be individual or collective, spontaneous or calculated, but they are united by a commitment to dreaming and enacting freedom.

Abolition, though traditionally associated with the successful movement to abolish slavery 
in the United States, has gained renewed attention followingthe longtime work of prison abolitionists such as Ruth Wilson Gilmore, Angela Davis, and Mariame Kaba. Davis (2005) has elaborated W.E.B. DuBois's (1938) conception of "abolitiondemocracy" - an imagined social organization, briefly enacted during Reconstruction, in which the principles of freedom were broadly applied to alland argued that prisons must be abolished. Gilmore (2007, 2017) has likewise theorized abolition extensively, noting in a recent interview with The Funambulist (2019) that:

Contemporary prison abolitionists have made this argument for more than two decades.

Abolition is not absence, it is presence.

What the world will become already exists in fragments and pieces, experiments and possibilities. So those who feel in their gut deep anxiety that abolition means knock it all down, scorch the earth and start something new, let that go. Abolition is building the future from the present, in all of the ways we can.

Abolition, in Gilmore's formulation, builds on the fugitive practices that already exist in the world, the "beautiful experiments" (Hartman, 2019) that, sheltered and sustained, flower into a future that is free.

\section{Fugitivity and Abolition in}

\section{Educational Scholarship}

Theories of abolition and fugitivity have increasingly been invoked in educational scholarship. In "Pedagogies of Resistance and Survivance: Learning as Marronage," Leigh Patel (2016) characterizes learning as a "fundamentally fugitive act" (p. 397). She challenges educators and educational researchers to recognize these "fugitive acts of learning" and to "differentiate those moments... from the seductive mollification of school-based achievement" (p. 397). Noting the stubborn conflation of learning with the production of test scores, Patel argues that we need theories of learning that complicate and supplant the emaciated ideal of achievement. Her theory's namesake, marronage, is the term applied to the overt and covert practices used by historically enslaved people to seek liberation. Marronage is "a practice of freedom that must, necessarily, start from the condition and category of enslavement in order to transgress it" (p. 401); Patel suggests that learning, too, can be understood as occurring in spite of, as a consequence of, and in the shadows of traditional schooling.

Along with racial capitalism, Patel identifies settler colonialism, a type of colonialism in which the settler as the organizing logic of traditional schooling. Indeed, in the United States, racial capitalism has always worked in tandem with settler colonialism, defined by Tuck and GaztambideFernandez (2013) as "the specific formation of colonialism in which the colonizer comes to stay, making himself the sovereign, and the arbiter of citizenship, civility, and knowing" (p. 73). This "logic of elimination" creates territorial claims and concomitant wealth generation through the ongoing erasure of indigenous peoples (Tuck and Gaztambide-Fernandez, 2013, p. 73). Settler colonialism and racial capitalism, manifesting as indigenous erasure and pervasive antiblackness, are thus inextricably linked in the production of capital in American society, and in this paper, I use the term racial capitalism with an understanding of its original relationship to colonialism and extraction (Robinson, 2005) and its contemporary 
relationship to settler colonialism in the United States. In Patel's formulation, learning exists in dialectical relationship to racial capitalism, a series of risky practices whose transformative potential is inherently unpredictable and liberatory.

A group of literacy scholars, the Fugitive Literacies Collective, has also taken up theories of fugitivityin their work on teaching and learning. In a recent special issue of English Education, guest editors Esther O. Ohito, Jamila Lyiscott, Laura Gonzales, and Mónica González Ybarra (2020) describe the Collective as "a constellation of critical scholar-friends of color... [who] think, study, write, and publish together in an intentional effort to irradiate the knowledges, complexities, and tensions that percolate when possibilities for the real or fictive liberation of historically marginalized and dehumanized persons and communities..." are taken seriously (p. 180).

In this issue, Ohito (2020) argues that attention to Black fugitivity in the literacy classroom confronts an ongoing problem in anti-racist literacy scholarship that frames white teachers and students as the protagonists and "Black people... as embodied reminders to white people that they, too, are raced" (p. 195). Fugitive literacy practices provide an opening for Black scholars to theorize the experience of Blackness "as something more than an abiding source of suffering and abjection" (p. 197, emphasis in original). Similarly, in the same issue, Lyiscott (2020) suggests that in a world that devours the public spectacle of Black pain, the private shared intimacies, cultural practices, and experiential wisdom of Black people are fugitive acts. Authors in this special issue ultimately coalesce around Ohito's definition of fugitive literacy practices as those that "involve creative uses of reading, writing, and oral language [along with a range of related cultural practices] as strategic tools for the curricular and pedagogic refusal of the hegemony of whiteness and anti-Blackness" ( $p$. 189).

Along with fugitivity, theories of abolition in educational practice have proliferated in the last few years. Abolitionist thinking in education grows outof attention to how education funnels racialized students into the carceral system through the School-to-Prison Pipeline (Christle et. al., 2005; Wald \& Losen, 2003), a metaphor that has since been troubled by scholars wishing to complicate our understandings of the relationship between prisons and schools. More recently, the terms school-toprison nexus (Meiners, 2007), school-prison nexus (Annamma, 2017; Krueger, 2010; Krueger-Henney, 2019), the prison-industrial complex (Meiners \& Winn, 2010), and the universal carceral apparatus (Shedd, 2015) have been taken up to suggest the complicated material and ideological manifestations of carceral logics in schools. Carceral logics deny Black and brown children access to the supposed innocence of childhood (Dumas \& Nelson, 2016; Meiners, 2016; Morris, 2015) and infuse schools with disciplinary policies, practices, and police, all of which disproportionately punish and exclude racialized children (Annamma, 2016; Crenshaw, 2012; Schynder, 2010; Shedd, 2015; Turner \& Benneke, 2020; Wun, 2015). As Rodriguez (2010) points out, "the carceral-cultural form of the prison has naturalized a systemic disorientation of the teaching act, so that teaching is no longer separable from the work of policing, juridical discipline, and state-crafted punishment" (p. 8).

Abolitionist approaches to educational research and practice are predicated on this understanding of schools as an extension of the carceral state. Abolition is "a messy breakup with the state" in 
contrast to liberal reforms, or even revolutionary ideologies, that seek to revise or "win control" over the state apparatus (Shange, 2020 p. 5). To imagine "abolitionist futures" in education "requires reconstructing the structures and traditions that safeguard power and privilege, just as much as taking down those that visibly punish and oppress" (Meiners \& Winn, 2010, p. 273), as well as shielding the "Black autonomous spaces"- the spaces that have allowed for the flourishing of Black creative life and freedom struggles that are often the explicit and implicit target of policing within and beyond schools (Sojoyner, 2016). Abolition "anticipates the task of remaking the world under transformed material circumstances" (Rodriguez, 2010, p. 15), asking us to work alongside young people, especially Black and brown students "whose imagination often [outpace] the mundane rituals of a standards-driven curriculum" (Schynder, 2010, p. 349).

Bettina Love's (2019) recent book We Want to do More Than Survive: Abolitionist Teaching and the Pursuit of Educational Freedom has propelled the term abolition into mainstream teacher education. Love draws on thinkers such as W.E.B. DuBois and Angela Davis, as well as the contemporary Black Lives Matter movement, to distinguish her abolitionist approach from traditional reformist models of school improvement. Whereas reform models encourage Black and brown students and families to survive in schools, to adapt to unjust conditions, abolitionist teaching calls on educators to dismantle the policies and practices that diminish and dehumanize students and families. Abolitionist teaching is thus both a theoretical stance-a vision for education that imagines its possibilities beyond its racist instantiations - and a daily practice of working in solidarity with communities of color.
Love's recommendations range from those that can be enacted in the classroom (curriculum development and pedagogical practice) to those that are school- and system-wide (equitable funding; ending exclusionary disciplinary practices and discriminatory standards for behavior and dress; abolish high-stakes testing; etc.)

Meanwhile, David Stovall's (2018) provocative call for "school abolition"" uses the framework for the abolition of the prison industrial complex to reimagine education beyond the material and ideological structures of traditional schooling. "Schooling" in its traditional sense- both as a literal place and as a set of ideologies about learning and behavior-is distinct from, if not explicitly antithetical to, education for liberation, instead relying on surveillance and containment to enforce narrow, Eurocentric ways of being and knowing. Stovall contrasts "school" with the liberatory educative agendas of historical slave rebellions, the Zapatistas in Mexico, the Quilombo movement in Brazil, and the Black Lives Matter uprisings in the United States and encourages us to consider how we might enact such educational possibilities in our own contexts. Thus, although broad in its vision, abolitionist teaching and learning requires sustained attention to the minute ways in which carceral logics permeate schools and the ways in which young people resist these mechanisms.

\section{Methods}

In this project, I employ an autoethnographic case study approach (Ellis et. al., 2010; Eisenhardt \& Graebner, 2007) to provide concrete examples of the oppressive structures and fugitive acts of learning that occur within Midwest High School, the urban high school where I taught for seven years. While not generalizable in the traditional sense, a case 
study is well-suited for theory building and allows us to understand more concretely what fugitive acts of learning might look like in one specific context (Eisenhardt \& Graebner, 2007). I explicitly engage in an autoethnographic case study to draw on the experiential insight I have gained as a teacher in this school (Ellis et. al., 2010). This specificity is important when considering colonial logics of erasure: claims of objectivity or universality actually center specific White, patriarchal, middleclass norms (Wynter, 2003). By looking closely at one school and centering my personal knowledge of this school, I try to honor the specificity of place and disturb universalizing Eurocentric epistemologies. I am also inspired by Davis et. al.'s (2020) recent provocation to look "closely at children's acts of contestations and moves to elsewhere," to highlight individual practices as they "emerge from social histories and carry future potentialities that shape learning and intellectual life within, and sometimes beyond, the setting" (p. 2). Indeed, Shange (2020) points out that "[a]s an analytic, abolition demands specificity - the very kinds of granularity that ethnography offers as an accounting of the daily practices that facilitate Black material and symbolic death" (p. 10).

I attempt to balance this close attention to detail with my desire to protect young people and their practices. Patel (2016) points out that slave narratives, for instance, "keep lots of details loose in order to protect the fugitive spirit of the ideas" (p. 400). Recognizing that undue attention to fugitive practices can lead to further restrictions and punishments, I maintain the anonymity of my students and their school and discuss their practices generally, rather than specifically.

Midwest High School is the only public high school in a small Northern Kentucky city just south of Cincinnati. The school is located in a workingclass community, and the student body is racially diverse: 46 percent self-identify as white, 33 percent self-identify as Black, 11 percent self-identify as Latinx, and 10 percent self-identify as multiracial. In my case study, I am draw from examples and practices that span racial categories. At the same time, I do not want to suggest that white students are surveilled to the same extent as Black students, or that the experience of a bilingual Latinx immigrant at Midwest High is the same as the experience of a Black student. It is necessary to explore the differential impacts of racial capitalism, but that project is beyond the scope of my autoethnographic case study. With Gonzalez et. al. (2020), who employ fugitive literacies to theorize the resistance practices of transfronterizx youth, I aim not to equate incommensurate student experiences but to contribute to the ongoing necessity of re-thinking our often carceral approaches to young people in schools.

\section{An Autoethnographic Case Study of Fugitive Learning at Midwest High School}

In this section, I explore three iterations of fugitive learning that I witnessed during my time as a teacher at Midwest High School. Following Patel's suggestion that learning must be understood in dialectic relation to oppressive structures, I organize each example of fugitive learning by first identifying a particular policy that serves to constrain students; I then explore the ways in which students subvert or creatively re-appropriate these mechanisms.

Repurposing Technologies that Control \& Surveilence

In 2016, Midwest High School implemented a 
1:1 initiative in which every student was assigned a laptop. Administrators and teachers attempted to control how laptops were used through a variety of techniques. The laptops were front-loaded with expensive scripted curricula that strictly dictated what students would be taught. The school also purchased surveillance technology that allowed teachers and administrators to remotely view and hijack student screens, to shut down computers, to send messages to students, and to lock them out of applications at any time. Popular websites like youtube, Facebook, and political news sites were blocked by the district and/or the state. These "unseemly realities of containment and profit" were "accepted obliquely under the umbrella of schooling and... wrongly associated with learning" (Patel, 2016, p. 397). Of course, surveillance isn't always high tech, and it isn't always expensive. At one staff meeting, our principal suggested that teachers organize our classrooms by lining the desks against walls, making the students face the wall so that we could surveil all of their computer screens simply by standing in the middle of the room. In other words, he unironically asked us to turn our classrooms into versions of the panopticon (Foucault, 1975).

But students found ways to evade censorship and to repurpose these technologies. They downloaded apps that provided answers to popular corporate curricula; they found proxies that gave them access to blocked websites; they used the messaging tool on the surveillance program to send messages back to teachers, saying "leave me alone" and "I'm not doing anything wrong." As a result of these workarounds, students were able to use their laptops as powerful tools for research and communication: they applied for jobs, chatted with friends, researched colleges, watched movies, made music, and read the news. Ironically, the laptops allow students to locate-either serendipitously or through targeted research_videos, articles, and social media posts that provide contextfor local injustices (e.g., sexist dress code) that they otherwise assume are individual or inevitable. In fact, it was through reading news online and through social media sites like Facebook that students learned about the nationwide March for Our Lives student protest in 2018 and were inspired to join. The laptops, meant to narrow opportunities for learning and control the content students encounter, became empowering tools that opened up "fundamentally unpredictable" possibilities for critical thinking, literacy, and solidarity (Patel, 2016, p. 399).

\section{Sharing Subversive Texts in a Standardized Curriculum}

One of the primary reasons Midwest High School purchased laptops was to prepare students more efficiently for high-stakes tests. In Kentucky, many high school classes culminate in corporate end-ofcourse assessments, and the content of these tests dictates the contours of the classroom curriculum. English teachers, for example, are required to structure their curriculum around decontextualized, culturally hegemonic nonfiction passages; multiplechoice questions; and brief on-demand writing exercises. These are the kinds of narrow literacies that students will encounter on standardized tests. Students at Midwest High were thus denied access to diverse literacies and culturally sustaining pedagogies (Morrell, 2008; Paris \& Alim, 2017; Skerret, 2010).

But within this prescribed curriculum, students found a "side street from the test score production factory mill of schooling" (Patel, 2016, p. 400). Students pursued their own diverse 
literacy practices, sharing subversive texts of all kinds: Snapchats, text messages, music, art, poetry, memes, gifs, and novels. None of these practices were school-sanctioned, especially those that involved communicating using cell phones.Indeed, even the once staid English class tradition of reading novels became fugitive in this context. There has been a huge influx of popular young adult novels in the last few years, of which The Hate U Give by Angie Thomas (2017) may be the most emblematic. Featuring a young Black girl whose unarmed friend is killed by a police officer in an all-too-familiar context, this book quickly became a best-seller for young people nationwide.

Students at Midwest High School found The Hate $U$ Give and similar books in the library and began reading them during their classes under their desks. Friends would badger one other: "When are you gonna be done? I want to read that." Yet these literacy practices rarely occurred as part of the official curriculum. When I tried to incorporate some of these texts as a simultaneous undercurrent to my official curriculum, my students began reading these novels in other classes, and some teachers called me to complain. They asked me if I could tell my students to stop reading in their class. Authentic literacy practices - reading, sharing, and discussing texts that have been deemed illicit-are fugitive acts in this school.

\section{Claiming The "Weak Spots" In A Restrictive} Schedule

Because so many courses culminate in high-stakes tests, the results of which are used to determine school performance ratings (and subsequent sanctions) in Kentucky, many classes are closely surveilled by the administration. This surveillance takes many forms: administrators conduct constant announced and unannounced walk-throughs, during which they check for daily learning objectives, standardized test practice, and student compliance. Administrators also ask teachers in these classes tosubmit raw data in the form of practice test results, and the analysis of these results, every six weeks. Teachers must submit unit plans, lesson plans, and yearlong curriculum maps. As a result, even teachers who may wish to supplement or eschew required curricular mandates are given few opportunities to do so.

As certain classes receive intense scrutiny, though, students can find untested, under-surveilled spaces and times, where there is more room for genuine conversation, exploration, and creation. Certain spaces are less subject to administrative or teacher control: the library, the cafeteria, counselor offices, and other non-instructional spaces can provide momentary refuge from a highly regimented schedule. At Midwest High School, students often gather in the library during lunch, before school, or during class time when they have finished assignments; the librarian teaches them to knit and recommends books. Each year, she hosts a chess tournament, and for weeks beforehand, dozens of students gather in the library to learn to play. The relaxed, collegial atmosphere of this space is a marked contrast to many classrooms. This supports the range of scholarly literature that confirms the importance of after-school activities for student learning (Eccles \& Templeton, 2002; Darling, 2005).

But even within the school day, certain times are less scrutinized than others. Lunch, elective classes, and the brief times between classes become momentary refuges from the otherwise carefully 
scheduled day. Even in closely monitored courses, however, certain times are more amenable to risky and transformative acts of learning. In the weeks following the administration of high stakes tests, for instance, most classes are under-surveilled, because the purpose of formal schooling - demonstrating mastery on an exam- has been accomplished. The days before and afterextended breaks from school are also less likely to be carefully monitored. Teachers and students use these more relaxed times in a variety of ways: they watch movies, plan outof-school events, read, debate and discuss, research topics of interest, play games, and write poems and stories. Though Midwest High School may not be a "place for transformation" (Patel, 2016, p. 397), within its walls, students, and sometimes teachers, carve out spaces for fugitive learning.

\section{Discussion}

In her recent book We Want to Do More than Survive: Abolitionist Teaching and Educational Freedom, Bettina Love (2018) argues that abolition is both a theoretical stance - a vision for education that imagines its possibilities beyond current racist school policies - and a daily practice of working in solidarity with communities of color. Abolition is essential in conceptions of learning as a fugitive act; when learning is fugitive, abolition is the process of dismantling the structures that force learning into secret "side streets" (Patel, 2016, p. 400). This dismantling can take many forms and addresses both the practical manifestations and ideological underpinnings of racial capitalism in schools.

Case studies in fugitive learning, drawing on the legacy of "radical scholarship [that] continues to make visible histories and pathways of resistance" (Meiners \& Winn, 2010, p. 273) can provide insight into the policies and ideologies that abolitionist teachers and researchers must target in their interventions. In locating sites of student resistance, repurposing, and evasion, we can untangle the specific policies and ideologies that create the conditions students subvert. In this section, I examine these conditions at Midwest High School and draw conclusionsabout which policies and ideologies require dismantling, along with which practices can be served and developed.

\section{Surveillance Technologies}

Surveillance technologies in schools reinvigorate racist legacies of hyper-surveillance of communities of color (Sewell et. al., 2016; Glover, 2008; Lewis, 2006; Raible \& Irrizarry, 2010). These technologies are part of the larger "carceral-cultural form of the prison [that] has naturalized a systemic disorientation of the teaching act, so that teaching is no longer separable from the work of policing, juridical discipline, and state-crafted punishment" (Rodriguez, 2010, p. 8). When schools assume that student access to content must be controlled, they reveal the lack of trust at the heart of their school culture and the assumptions that students will misuse and abuse freedom. Educational practitioners can combat these policies on a local level-turning off these technologies in their own classrooms, advocating for its abolition at the school and district level — and researchers can investigate the impacts these technologies have on student learning and school culture. As Love (2018) argues, though, abolition is not merely dismantling - it is also imagining and building a different reality. Abolitionist teachers and researchers must ask: What does a school look like when it trusts its students? What happens when students are given 
the freedom to use tools and technologies to their full creative potential?

\section{High-Stakes Tests And Narrow Curricula}

High-stakes tests have been consistently delegitimized as adequate measures of learning (Berliner, 2011; Fisher-Ari et. al., 2017; Knoester $\& \mathrm{Au}, 2017)$, and some communities have fought to reduce reliance on testing in schools (Mitra et. al., 2018; Crowder \& Konle, 2015). However, standardized testing persists in many schools (Au, 2016). Abolitionist researchers and practitioners must continue to advocate for the diminished reliance on testing in schools and to imagine alternative curricula and assessments that are inspired by actual student literacy practices. At Midwest High School, students read young adult literature and constantly communicate and share resources using computers and cell phones. Practitioners can develop their own curricula that center these resources, and they can advocate for students who engage in these literacy practices, shielding them from administrative control, teacher criticism, and punitive disciplinary measures. Researchers, meanwhile, some of whom already consider the everyday literacy practices of students outside of school (Gutierrez et. al., 2017) can consider what everyday literacy practices in schools look like and how these practices can be incorporated more systemically into schools.

\section{Non-Academic Spaces}

While surveillance technologies, high stakes tests, and narrow curricula necessitate dismantling, non-academic spaces in school require support. Schools are structured by racial capitalism, but within them, students find spaces of refuge that can be collaborative, generative, and enjoyable. Abolitionist researchers and practitioners must recognize the value of these offices, libraries, and elective courses (Eccles \& Templeton, 2002; Darling, 2005; Goodin, 2010; Kachel, 2011), both documenting their value and actively protecting their existence in schools that are constantly seeking to cut funding to "non-essential" elements (Ravitch, 2016). Although certain spaces, like libraries, are almost universally important in schools, the meanings of many non-academic spaces are contextually contingent. In one school, the college counselor office might be the place of refuge; in another, the gym might serve this function; and in most schools, multiple spaces will serve different students. Abolitionist researchers and practitioners can also investigate more seriously specific times in the year, looking for and building on important learning that might happen after testing or around long breaks. This research requires sustained engagement with schools and students to learn to the specific places and times that yield transformative learning.

Ultimately, as abolitionist researchers and practitioners "learn to see" (Gutierrez et al., 2017) fugitive learning in schools, we simultaneously set ourselves up to gather information about the racial capitalist policies we want to dismantle - and the practices we want to serve, shield, and build on in educational spaces.

\section{Conclusion}

This case study suggests that fugitive learning in schools exists in dialectic relationship to particular manifestations of racial capitalism and settler colonialism. At Midwest High School, these structures manifest in an over-reliance on restrictive technology, a narrow emphasis on tests, and the hyper-surveillance of certain spaces and the devaluing of others. Student resistance occurs in 
response to these particularities: students creatively appropriate technologies that are meant to control and constrict their learning opportunities; they share subversive texts within curricula that rely on narrow definitions of literacy; and they take advantage of under-surveilled spaces and times in a generally rigid school schedule. While the case study in this article examines a limited set of practices at a single school, it provides a valuable starting point for research into the nature of racial capitalism and settler colonialism manifest in schools, and how and when "intermittent departures" from these oppressive structures occur (Patel, 2016, p. 401). Further research is needed to investigate how these piecemeal practices have been or could be developed into larger projects of transformative learning in the service of abolition. However, we must also acknowledge the fugitive learning that we do not see, as adults; as well, those of us who are white must acknowledge that fugitive learning that may be illegible to us. As Shange (2020) reminds us, sometimes we must commit to "care more than we can know" - to support our students, and to assume they are always learning and creating, regardless of whether their learning and creation is immediately available to us (p. 10). Fugitive learning and abolitionist practice require imagination, a vision that draws on the "beautiful experiments" of the present to envision a future in which we are all free (Hartman, 2019).

\section{REFERENCES}

Annamma, S. A. (2016). DisCrit: Disability studies and critical race theory in education. Teachers College Press.

Annamma, S. A. (2017). The pedagogy of

pathologization: Dis/abled girls of color in the school-prison nexus. Routledge.
Au, W. (2016). Meritocracy 2.0: High-stakes, standardized testing as a racial project of neoliberal multiculturalism. Educational Policy, 30, 39-62. 10.1177/0895904815614916.

Berliner, D. (2011). Rational responses to high stakes testing: The case of curriculum narrowing and the harm that follows. Cambridge Journal of Education, 41(3): 287-302. https://doi.org/10.10 80/0305764X.2011.607151.

Christle, C. A., Jolivette, K., \& Nelson, C. M. (2005). Breaking the school to prison pipeline: Identifying school risk and protective factors for youth delinquency. Exceptionality, 13(2), 69-88. Cook-Sather, A, and Alter, Z. (2011). What is and what can be: How a liminal position can change learning and teaching in higher education. Anthropology \& Education Quarterly, 42(1), 37-53.

Crenshaw, K. W. (2017). On intersectionality: Essential writings. The New Press.

Crowder, Z., \& Konle, S. (2015). Gumbo ya-ya or, what Pearson can't hear: Opt-out, standardized testing, and student surveillance. The High School Journal, 98(4), 285-289.

Darling, N., Caldwell, L., \& Smith, R. (2005). Participation in school-based extracurricular activity and adolescent adjustment. Journal of Leisure Research, 37, 51-76

Davis, A. Y. (2011). Abolition democracy: Beyond empire, prisons, and torture. Seven Stories Press. Davis, N. R., Vossoughi, S., \& Smith, J. F. (2020). Learning from below: A micro-ethnographic account of children's self-determination as sociopolitical and intellectual action. Learning, Culture and Social Interaction, 24, 100373.

Du Bois, W. E. B. (1935). Black reconstruction: An essay toward a history of the part which black folk played in the attempt to reconstruct democracy 
in America, 1860-1880. Harcourt, Brace.

Dumas, M. J., \& Nelson, J. D. (2016).

(Re)Imagining Black boyhood: Toward a critical framework for educational research. Harvard Educational Review, 86(1), 27-47.

Eccles, J., \& Templeton, J. (2002). Extracurricular and other after-school activities for youth. Review of Research in Education, 26, 113-180.

Eisenhardt, K. M., \& Graebner, M. E. (2007).

Theory building from Cases: Opportunities and challenges. Academy of Management Journal, 50(1), 25-32. doi:10.5465/ amj.2007.24160888

Ellis, C, Adams, T.E., and Bochner, AP. (2010). Autoethnography: An Overview. Forum: Qualitative Social Research, 12(1). https://doi. org/10.17169/fqs-12.1.1589.

Fisher-Ari, T., Kavanagh, K. M., \& Martin,

A. (2017). Sisyphean neoliberal reforms: The intractable mythology of student growth and achievement master narratives within the testing and TFA era. Journal of Education Policy, 32(3), 255-280. https://doi.org/10.1080/02680939.201

\subsection{6}

Foucault, M. (1977). Discipline and punish: The birth of the prison. New York: Pantheon Books.

Gilmore, R. W., \& Lo, L. (2019). Making abolition geography in California's Central Valley with Ruth Wilson Gilmore. The Funambulist, 21.

Gilmore, RW. (2017). Abolition Geographies and the problem of innocence. In Johnson, Gaye Theresa, and Alex Lubin, eds. Futures of Black Radicalism. Verso.

Glover, K. S. (2008). Citizenship, hypersurveillance, and double-consciousness: Racial profiling as panoptic governance. In M. Deflem \& J. T. Ulmer (Eds.), Surveillance and governance:
Crime control and beyond (Vol. 10, pp. 241-256). Emerald Group Publishing Limited. https://doi. org/10.1016/S1521-6136(07)00211-4

Gonzales, L., \& Ybarra, M. G. (2020). Multimodal Cuentos as Fugitive Literacies on the Mexico-US Borderlands. English Education, 52(3), 223-255. Goodin, S.M. (2010). Steps Towards Unifying Literacy Theory and Librarianship. CSLA Journal, 34(1): 24-25.

Gutiérrez, K. D., Cortes, K., Cortez, A., DiGiacomo, D., Higgs, J., Johnson, P., ... \& Vakil, S. (2017). Replacing representation with imagination: Finding ingenuity in everyday practices. Review of Research in Education, 41(1), 30-60.

Harney, S. and Moten, M. (2013.) The undercommons: Fugitive planning and black study. Wivenhoe: Minor Compositions.

Harvey, D. (2004). The new imperialism:

Accumulation by dispossession. Socialist Register. 40.

Kachel, D. E. (2011). School Library Research Summarized: A Graduate Class Project. Mansfield University.

Kavanagh, K.M., and Fisher-Ari, T.R. (2018).

Curricular and Pedagogical Oppression: Contradictions Within the Juggernaut Accountability Trap. Educational Policy, https:// doi.org/10.1177/0895904818755471.

Kelley, R. D. (2002). Freedom dreams: The black radical imagination. Beacon Press.

Kelley, R. D. (2016). Black Study, Black Struggle| Boston Review.

Knoester, M., and Au, W. (2017). "Standardized Testing and School Segregation: Like Tinder for Fire?" Race, Ethnicity and Education 20(1): 1-14. https://doi.org/10.1080/13613324.2015.11 21474. 
Krueger-Henney, P. (2019). Through space into the flesh: Mapping inscriptions of anti-black racist and ableist schooling on young people's bodies. Curriculum Inquiry, 49(4), 426-441.

Krueger, P. (2010). It's not just a method! The epistemic and political work of young people's lifeworlds at the school-prison nexus. Race Ethnicity and Education, 13(3), 383-408.

Lewis, T. (2006). Critical surveillance literacy. Cultural Studies $\leftrightarrow$ Critical Methodologies, 6, 263-281.

Love, B. (2019). We want to do more than survive: Abolitionist teaching and the pursuit of educational freedom. Boston, MA: Beacon Press.

Lyiscott, J. (2020). Fugitive Literacies as Inscriptions of Freedom. English Education, 52(3), 256-263.

Meiners, E. R. (2007). Right to Be Hostile: Schools. Prisons, and the Making of Public Enemies (New York, 2007).

Meiners, E. R. (2016). For the children?: Protecting innocence in a carceral state. $U$ of Minnesota Press.

Meiners, E. R., \& Winn, M. T. (2010). Resisting the school to prison pipeline: The practice to build abolition democracies. Race Ethnicity and Education, 13(3), 271-276.

Mitra, D., Mann, B., \& Hlavacik, M. (2016). Opting out: Parents creating contested spaces to challenge standardized tests. education policy analysis archives, 24, 31 .

Morrell, E. (2008). Critical Literacy and Urban Youth: Pedagogies of Access, Dissent, and Liberation. New York: Routledge.

Morrell, E. (2015). Critical literacy and urban youth: Pedagogies of access, dissent, and liberation. New York: Routledge

Morris, M. (2016). Pushout: The criminalization of Black girls in schools. New Press, The.

Moten, F. (2003). In the break: The aesthetics of the black radical tradition. $\mathrm{U}$ of Minnesota Press.

Ohito, E. O. (2020). " The creative aspect woke me up": Awakening to Multimodal Essay Composition as a Fugitive Literacy Practice. English Education, 52(3), 186-222.

Paris, D., \& Alim, H. S. (2017). Culturally sustaining pedagogies: Teaching and learning for justice in a changing world.

Patel, L. (2016). Pedagogies of resistance and survivance: Learning as marronage. Equity \& Excellence in Education, 49(4), 397-401. doi:1 $0.1080 / 10665684.2016 .1227585$

Patel, L. (2019). Fugitive practices: Learning in a Settler Colony. Educational Studies, 1-9.

Quan, H. L. T. (2017). “It's Hard to Stop Rebels that Time Travel": Democratic Living and the Radical Reimagining of Old Worlds. In Futures of Black Radicalism (pp. 173-193). Verso.

Raible, J., \& Irizarry, J. G. (2010). Redirecting the teacher's gaze: Teacher education, youth surveillance and the school-to-prison pipeline. Teaching and Teacher Education, 26(5), 1196-1203.

Ravitch, D. (2016). The death and life of the great American school system: How testing and choice are undermining education. New York: Basic Books.

Robinson, Cedric J. (2005). Black marxism: The making of the Black radical tradition. Chapel Hill: University of North Carolina Press.

Schnyder, D. (2010). Enclosures abound: Black cultural autonomy, prison regime and public education. Race Ethnicity and Education, 13(3), 
349-365.

Sewell, W., Horsford, C. E., Coleman, K., \& Watkins, C. S. (2016). Vile vigilance: An integrated theoretical framework for understanding the state of Black surveillance. Journal of Human Behavior in the Social Environment, 26, 1-16.

Shange, S. (2019). Progressive Dystopia: Abolition, Antiblackness, and Schooling in San Francisco. Duke University Press.

Sharpe, C. (2014). Black life, annotated. The New Inquiry, 8.

Sharpe, Christina. (2014). "Black Life, Annotated." The New Inquiry (blog), August 8, 2014. https:// thenewinquiry.com/black-life-annotated/.

Shedd, C. (2015). Unequal city: Race, schools, and perceptions of injustice. Russell Sage Foundation.

Skerrett, A. (2010). Teaching critical literacy for social justice. Action in Teacher Education, 31(4), 54-65.

Smith, L. T. (2012). Decolonizing methodologies: Research and indigenous peoples. London: Zed Books.

Sojoyner, D. M. (2016). First strike: Educational enclosures in black Los Angeles. U of Minnesota Press.

Stovall, D. (2018). Are we ready for 'school'abolition?: Thoughts and practices of radical imaginary in education. Taboo: The Journal of Culture and Education, 17(1), 6.

The Fugitive Literacies Collective, 2020 - editors

Esther O. Ohito, Jamila Lyiscott, Laura Gonzales, and Mónica González Ybarra (2020)

Tuck, E., \& Yang, K. W. (2012). Decolonization is not a metaphor. Decolonization: Indigeneity, Education, \& Society, 1(1), 1-40.

Tuck, E., and Gaztambide-Fernández., R.A. (2013). Curriculum, Replacement, and Settler Futurity.
Journal of Curriculum Theorizing, 29(1): 18.

Turner, E. O., \& Beneke, A. J. (2020).

'Softening'school resource officers: the extension of police presence in schools in an era of Black Lives Matter, school shootings, and rising inequality. Race Ethnicity and Education, 23(2), 221-240.

Turner, V. W. (1969). The ritual process: Structure and anti-structure. Chicago: Aldine Pub. Co.

Vossoughi, S., \& Gutiérrez, K. D. (2016). Critical pedagogy and sociocultural theory. In Power and Privilege in the Learning Sciences: Critical and Sociocultural Theories of Learning (pp. 139-161). Taylor and Francis. https://doi. org/10.4324/9781315685762

Vossoughi, S., \& Gutiérrez, K. D. (2016). Critical pedagogy and sociocultural theory. In Power and Privilege in the Learning Sciences: Critical and Sociocultural Theories of Learning (pp. 139-161). Taylor and Francis. https://doi. org/10.4324/9781315685762

Wald, J., \& Losen, D. J. (2003). Defining and redirecting a school to prison pipeline. New directions for youth development, 2003(99), 9-15.

Wun, C. (2016). Against captivity: Black girls and school discipline policies in the afterlife of slavery. Educational Policy, 30(1), 171-196.

Wynter, S. (2003). Unsettling the Coloniality of Being/Power/Truth/Freedom, CR: The New Centennial Review 3(3): 257-337. 


\section{ABOUT THE AUTHOR}

Karen Zaino is a doctoral student in Urban Education at the CUNY Graduate Center and a Teaching Fellow in the CUNY Queens College English Education Department. Prior to graduate study, she was a high school English teacher for 12 years in Philadelphia, PA and Covington, KY. She can be reached atkzaino@gmail.com. 